\title{
Adsorption of obsolete silt, peat, sawdust and compositions of them
}

\author{
Zh.O. Petrova (ORCID 0000-0001-7385-8495), K.M. Samoilenko (ORCID 0000-0002-5169-4466), \\ Yu.P. Novikova (ORCID 0000-0002-6705-1000), T.A. Vyshnievska (ORCID0000-0001-7505-4175) \\ Institute of Engineering Thermophysics of NAS of Ukraine, str. Bulakhovskogo, 2, Bldg. 1, Kyiv, 03164, Ukraine \\ Tel.: +380444249639, +380503551610,+380664767825,+380635275640 \\ E-mail: bergelzhanna@ukr.net,samoilenkokm@nas.gov.ua,yuliianovikova3@gmail.com,vyshnievskat@gmail.com
}

Article info: received 03.05.2021, revised 12.05.2021, accepted 27.05.2021

Petrova, Zh.O., Samoilenko, K.M., Novikova, Yu.P., Vyshnievska, T.A. (2021) Adsorption of obsolete silt, peat, sawdust and compositions of them, 2(51), DOI: 10.26909/csl.1.2021.2

Environmental security is an important part of Ukraine's national security. It provides for the maintenance and improvement of the environment and should have a set of measures to prevent the danger to the population. One of the important issues of environmental safety in Ukraine is the accumulation of obsolete sludge after wastewater treatment at aeration stations. Untreated sludge has been merging into overcrowded sludge sites for several decades, which has led to the deterioration of the environment and living conditions in Ukraine.

The article presents experimental studies to determine the adsorption properties of granules based on the composition of sludge and peat with the addition of sawdust. Preparation of raw materials, creation of compositions and granulation from obsolete sludge, peat and biomass were covered in previous publications.

Key words: sludge, peat, sawdust, compositions, adsorbtion.

\section{Адсорбція застарілих мулових відкладень, торфу, тирси та композицій $з$ них}

\author{
Ж.О. Петрова, К.М. Самойленко, Ю.П. Новікова, Т.А. Вишнєвська \\ Інститут технічної теплофізики НАН України, м. Київ, Украӥна
}

Екологічна безпека є важливою ланкою національної безпеки України. Вона передбачає підтримання та поліпшення стану навколишнього середовища та повинна мати комплекс заходів щодо запобігання виникнення небезпеки для населення. Однією із важливих питань екологічної безпеки в Україні є нагромадження застарілих мулових відкладень після очистки стічних вод на станціях аерації. Необроблені мулові осади протягом декількох десятків років зливаються на переповнені мулові майданчики, що призвело до погіршення екології та умов життя в Україні [1].

У статті представлено експериментальні дослідження визначення адсорбційних властивостей гранул на основі композиції з осаду та торфу з додаванням тирси, як наповнювача в технології виготовлення керамічних виробів. Підготовка сировини, створення композицій та гранулоутворення з застарілих мулових відкладень, торфу та біомаси було висвітлено в попередніх публікаціях [2].

Ключові слова: мулові відкладення, торф, тирса, композиції, адсорбція.

\section{Вступ}

При розробці технології переробки застарілих мулових відкладень та одержання композицій із додаванням до них торфу та тирси важливе значення має рівноважна вологість, що визначає не тільки умови їх зберігання, а і кінцевий вологовміст при сушінні.
Рівноважна вологість - це вміст вологи, при якому матеріал не набирає і не втрачає вологу. Значення рівноважної вологості залежить від структури матеріалу, відносної вологості та температури повітря, 3 яким він контактує. Швидкість, з якою настає рівноважна вологість, залежить від властивостей матеріалу, співвідношення площі поверхні до об'єму його 
форми та швидкості, з якою волога переноситься [3]. Рівноважна вологість $\epsilon$ одним із основних показників при зберіганні. Від цього показника залежить кінцевий вологовміст та енергетичні затрати на процес зневоднення.

Мета роботи полягає у проведенні досліджень для визначення адсорбційних властивостей торфу, мулових відкладень, тирси та композицій з них, що можуть бути використані як наповнювач в технології виготовлення керамічних виробів.

\section{Матеріали та методи дослідження}

Для визначення рівноважної вологості дослідних зразків в залежності від відносної вологості повітря $\varphi$ застосовувався тензометричний (статичний) метод Ван Бамелена [3]. Суть методу полягає в тому, що зразки матеріалу, з наперед визначеним вологовмістом, витримують в ексикаторах над водними розчинами сірчаної кислоти. Відомій концентрації розчинів відповідає при даній температурі певний парціальний тиск пари, тобто відповідне значення відносного тиску $p / p_{s}$.

Потенціалом перенесення в процесі адсорбції $€$ парціальний тиск пари. Рівновага в системі настає коли парціальні тиски водяної пари в повітрі $p_{n п о в}$ та пари в тонкому шарі над матеріалом $p_{\text {пмат }}$ вирівнюються (тобто при $p_{\text {повв }}=p_{\text {пмат }}$ ) при рівності значень температури повітря і матеріалу. В цих умовах матеріал приймає сталу відносну вологість $\mathrm{W}_{\mathrm{p}}$, що називають рівноважною, причому рівновагу в системі розуміють лише, як динамічну. Якщо матеріал набирає вологу $p_{\text {ппов }}>p_{\text {пмат }}-$ йде сорбція, якщо віддає вологу $\left(p_{\text {ппов }}<p_{\text {пмат }}\right),-$ йде десорбція.

У рівноважному стані вологість матеріалу $W p$ однакова в будь-якій його точці.

Вміст водяної пари в повітрі прийнято визначати відносною вологістю повітря $\varphi$, що дорівнює відношенню парціального тиску пари повітря $p_{n \text { nов }}$ до тиску насичення $p_{\text {нас }}$ при тій же температурі над водою.

Оскільки в довідковій літературі наведена залежність тиску водяної пари над розчинами сірчаної кислоти $\left(\mathrm{H}_{2} \mathrm{SO}_{4}\right)$ в мм рт. ст. від концентрації $\mathrm{H}_{2} \mathrm{SO}_{4}$ у вагових \%, проведений перерахунок даного тиску на відносну вологість $\varphi$ за формулою

$$
\varphi=\frac{p}{p_{S}}
$$

де $p$ та $p_{s}$ - парціальний тиск та тиск насичення водяної пари при тиску 760 мм рт. ст. і температурах, що охоплюють можливий діапазон їх зміни в експерименті. Результати перерахунку надані в таблиці 1.

У довідниках в табличній формі наведена залежність тиску водяної пари над розчинами від вагових \% $\mathrm{H}_{2} \mathrm{SO}_{4}$ в розчині (тобто від іiі концентрації), а також залежність вмісту $\mathrm{H}_{2} \mathrm{SO}_{4}$ в грамах на 100 г розчину і на 1 літр розчину від густини розчину при $20{ }^{\circ} \mathrm{C}$ для кислоти густиною 1,8305 г/ $\mathrm{cm}^{3}$ [3].

Відповідно до техніки приготування розчинів були підготовлені 4 розчини для 4 різних $\varphi$ в діапазоні від 0,4 до 0,9. Експерименти проводились при температурі навколишнього повітря $18-20^{\circ} \mathrm{C}$.

Оскільки рівноважну вологість доцільно розраховувати по відношенню до абсолютно сухої маси матеріалу, тому що ця величина в процесах сорбції - десорбції і сушіння-зволоження залишається незмінною, то при обробленні всіх експериментальних даних маса вологи, що була поглинена матеріалом, віднесена до маси абсолютно сухого матеріалу.

Таким чином, були одержані ізотерми сорбції $W_{p}^{c}=f(\varphi)$ у дослідженому інтервалі відносної вологості повітря та криві кінетики сорбції $W^{c}=f(\tau)$, оскільки у схемі експерименту передбачена також можливість фіксування зміни відносної вологості зразків у часі.

Таблиця 1.

Рівняння експериментальних ізотерм адсорбції

\begin{tabular}{|l|c|c|}
\hline \multicolumn{1}{|c|}{ Матеріал } & Рівняння експериментальних ізотерм & $\begin{array}{c}\text { Рівняння лінеарі- } \\
\text { оованих ізотерм }\end{array}$ \\
\hline Торф & $\mathrm{W}=21,0376 \varphi^{3}+32,2698 \varphi^{2}-39,0201 \varphi+20,4774$ & $\mathrm{~W}=5,2576 \mathrm{e}^{1,7387 \phi}$ \\
\hline Мулові відкладення & $\mathrm{W}=72,7388 \varphi^{3}-107,5176 \varphi^{2}+53,2690 \varphi-6,9790$ & $\mathrm{~W}=0,5068 \mathrm{e}^{2,71 \phi}$ \\
\hline Тирса & $\mathrm{W}=-39,495 \varphi^{3}+130,52 \varphi^{2}-93,686 \varphi+26,275$ & $\mathrm{~W}=2,9577 \mathrm{e}^{1,9981 \phi}$ \\
\hline $\begin{array}{l}\text { Двокомпонентна композиція на ос- } \\
\text { нові торфу та мулових відкладень }\end{array}$ & $\mathrm{W}=70,1308 \varphi^{3}-92,2586 \varphi^{2}+42,6232 \varphi-1,6759$ & $\mathrm{~W}=2,1853 \mathrm{e}^{1,8761 \phi}$ \\
\hline $\begin{array}{l}\text { Трьохкомпонентна композиція на } \\
\text { основі торфу, мулових відкладень } \\
\text { та тирси }\end{array}$ & $\mathrm{W}=32,606 \varphi^{3}-13,13 \varphi^{2}-6,3313 \varphi+8,634$ & $\mathrm{~W}=2,5349 \mathrm{e}^{1,9641 \phi}$ \\
\hline
\end{tabular}




\section{Результати та їх обговорення}

Отримані в результаті дослідів кінетичні криві адсорбції водяної пари над торфом представлені на рис. 1. Кінетичні криві адсорбції свідчать про повільне протікання процесу. Так для торфу при значенні $\varphi=0,4$ (рис. 1 , крива 1) рівноважний стан встановлюється на 19 добу; при $\varphi=0,6$ (рис. 1, крива 2) на 15 добу; при $\varphi=0,8$ (рис. 1, крива 3) на 22 добу; при $\varphi=0,9$ (рис. 1, крива 4) на 34 добу. Рівноважна вологість торфу при $\varphi=0,6$ складає $12 \%$.

На рис. 2 наведені кінетичні криві для мулових відкладень. Останні, в порівнянні з торфом, мають нерівномірний характер, 32 по 5 день проходять стрибки при значеннях відносної вологості 0,4; 0,6; 0,8 ; при $\varphi=0,9$ стрибок з'являється на 15 день. Для мулових відкладень рівноважний стан встановлюється при $\varphi=0,4$ (рис. 2, крива 1) на 19 добу; при $\varphi=0,6$ (рис. 2, крива 2) на 15 добу; при $\varphi=0,8$ (рис. 2, крива 3) на 30 добу; при $\varphi=0,9$ (рис. 2, крива 4) на 34 добу. Рівноважна вологість мулових відкладень складає при $\varphi=0,6$ складає $2 \%$.

Як видно 3 кінетичних кривих адсорбції над тирсою (рис. 3), рівноважний стан встановлюється при $\varphi=0,4$ (рис. 3, крива 1) на 11 добу; при $\varphi=0,6$ (рис. 3 , крива 2) на 18 добу; при $\varphi=0,8$ (рис. 3, крива 3) на 30 добу; при $\varphi=0,9$ (рис. 3, крива 4) на 34 добу. Рівноважна вологість тирси при $\varphi=0,6$ складає $9 \%$.

Кінетичні криві адсорбції над двокомпонентною композицією на основі мулових відкладень та торфу зображені на рис. 4. Рівноважний стан у двокомпонентної композиції встановлюється при $\varphi=0,4$ (рис. 4, крива 1) на 8 добу; при $\varphi=0,6$ (рис. 4, крива 2) на 7 добу; при $\varphi=0,8$ (рис. 4, крива 3) на 28 добу; при $\varphi=0,9$ (рис. 4, крива 4) на 34 добу. Рівноважна вологість при $\varphi=0,6$ двокомпонентної композиції складає $6 \%$.

Кінетичні криві адсорбції над трьохкомпонентною композицією на основі мулових відкладень,

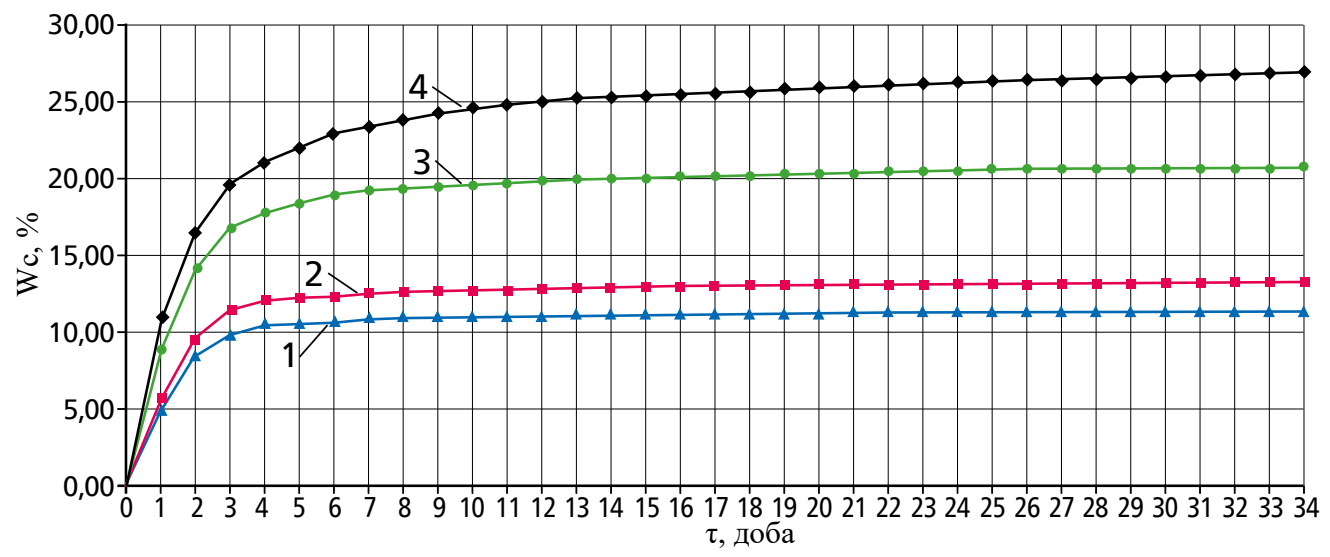

Рис. 1. Кінетичні криві адсорбції водяної пари над торфом: $1-\varphi=0,4 ; 2-\varphi=0,6 ; 3-\varphi=0,8 ; 4-\varphi=0,9$

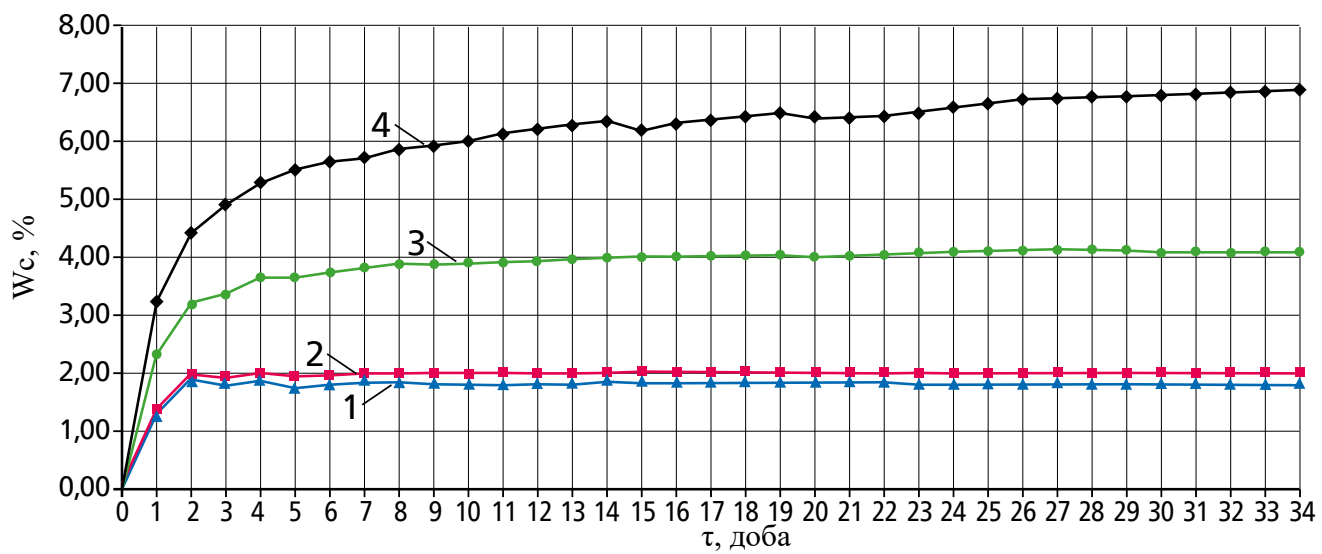

Рис. 2. Кінетичні криві адсорбції водяної пари над муловими відкладеннями:

$$
1-\varphi=0,4 ; 2-\varphi=0,6 ; 3-\varphi=0,8 ; 4-\varphi=0,9
$$


торфу та тирси зображені на рис. 5. івноважний стан у трьохкомпонентної композиції встановлюється при $\varphi=0,4$ (рис.5, крива 1) на 14 добу; при $\varphi=0,6$ (рис. 5, крива 2) на 15 добу; при $\varphi=0,8$ (рис. 5, крива 3) на 27 добу; при $\varphi=0,9$ (рис. 5, крива 4) на 29 добу.
Рівноважна вологість трьохкомпонентної композиції при $\varphi=0,6$ складає $7 \%$.

Кінетичні криві адсорбції дво- та трьохкомпонентної композицій мають характер кривих мулових відкладень. При відносній вологості пові-

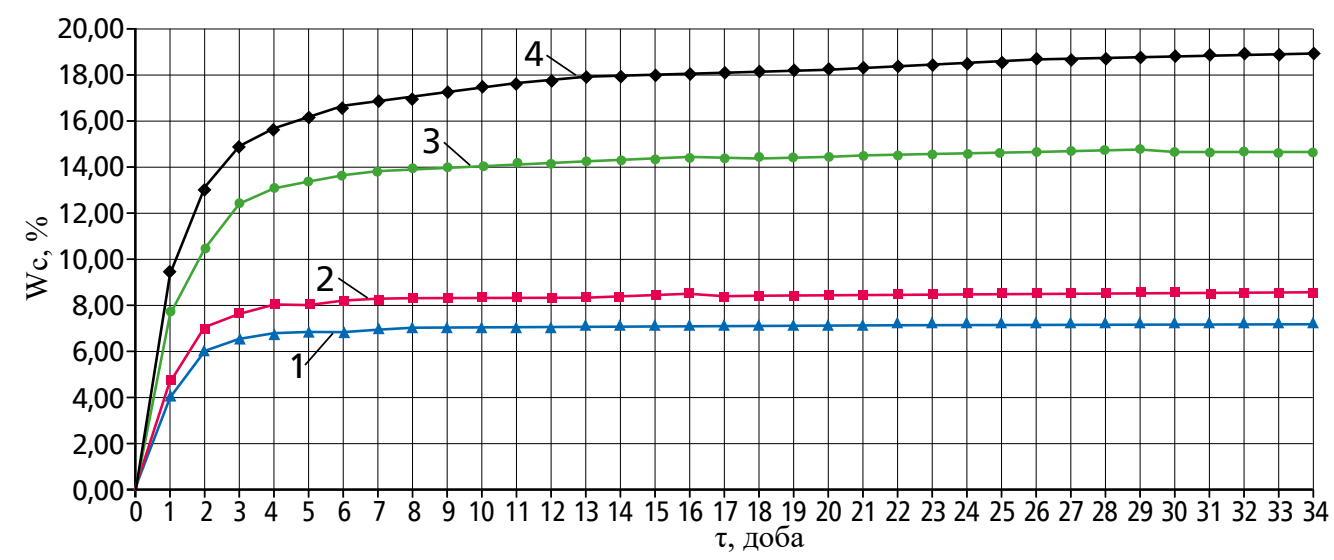

Рис. 3. Кінетичні криві адсорбції пари водяної над тирсою: $1-\varphi=0,4 ; 2-\varphi=0,6 ; 3-\varphi=0,8 ; 4-\varphi=0,9$

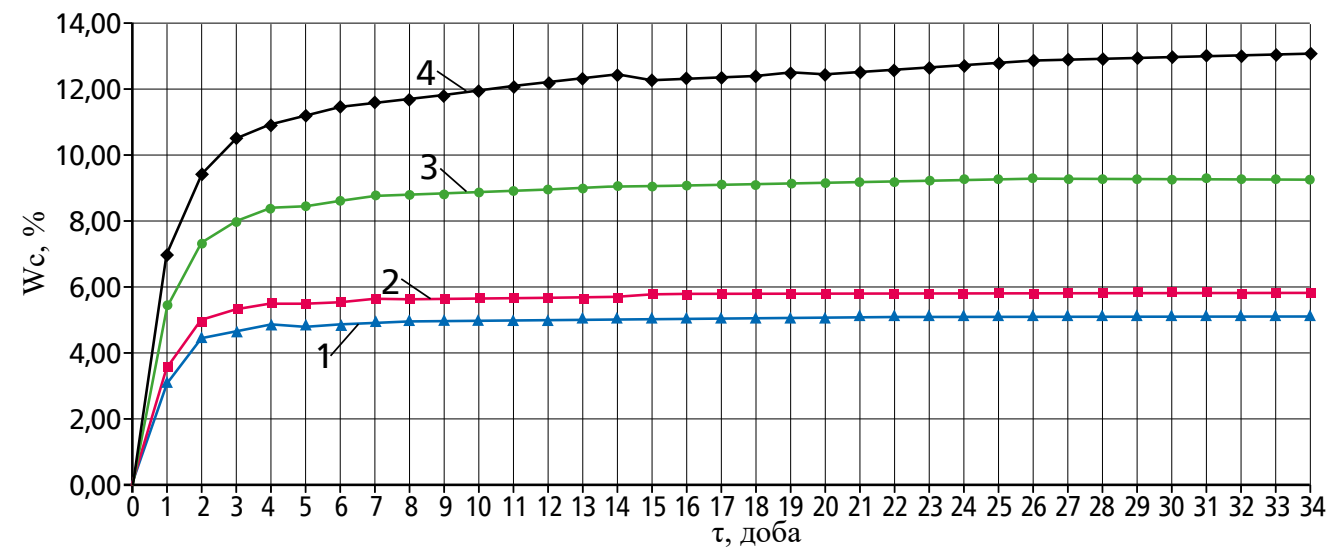

Рис. 4. Кінетичні криві адсорбції водяної пари над двокомпонентною композицією на основі мулових відкладень та торфу: $1-\varphi=0,4 ; 2-\varphi=0,6 ; 3-\varphi=0,8 ; 4-\varphi=0,9$

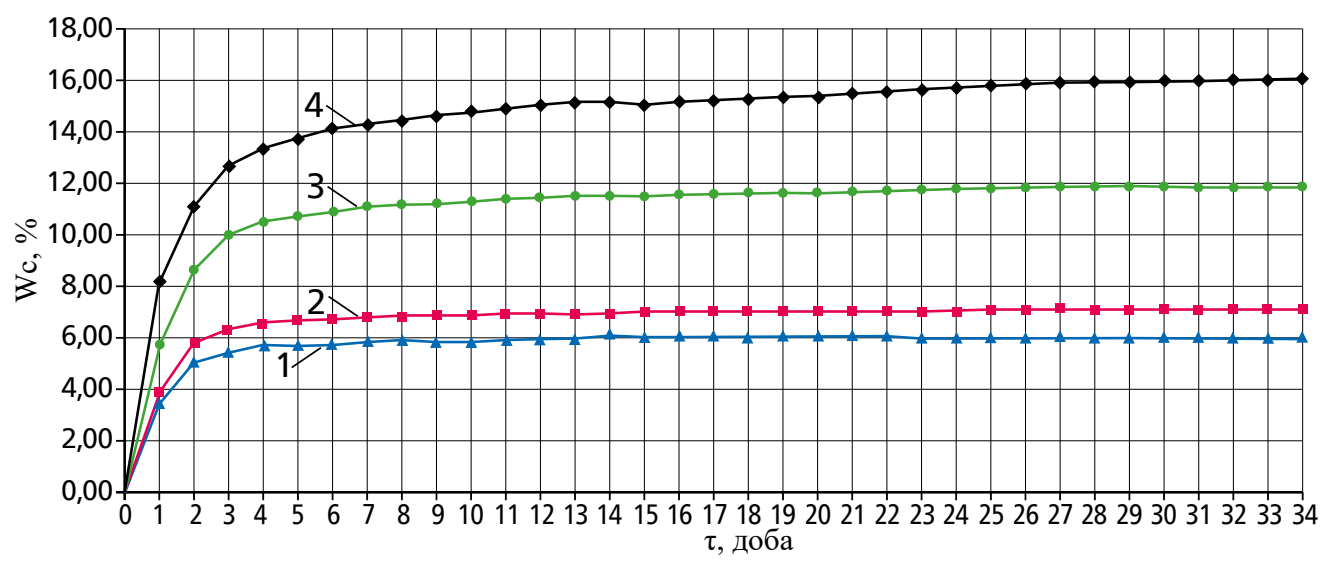

Рис. 5. Кінетичні криві адсорбції водяної пари над трьохкомпонентною композицією на основі мулових відкладень, торфу та тирси: $1-\varphi=0,4 ; 2-\varphi=0,6 ; 3-\varphi=0,8 ; 4-\varphi=0,9$ 
тря $\varphi=0,6$ рівноважна вологість торфу складає близько $12 \%$; мулових відкладень - $2 \%$; тирси - 9\%; двокомпонентної композиції - $6 \%$; трьохкомпонентної композиції - 7 \%.

Аналіз експериментальних ізотерм дозволяє віднести їх до ізотерм адсорбції IV типу по класифікації Брунуера, Демінга, Демінга і Теллера (БДДТ). Ізотерми IV типу спостерігаються у неорганічних оксидів та у інших пористих тіл, для яких також наявні петлі гістерезису [4]. Існуючі петлі гістерезису $є$ наслідком неповної необоротності процесів випаровування та конденсації. На експериментальних кривих петлі гістерезису знаходяться в області низького відносного тиску. Ïх наявність можна пояснити особливостями матері- алу та властивістю води як адсорбату. Ізотерми при більшому відносному тиску зворотні та крива буде спрямована вгору [5].

Криві ізотерм адсорбції торфу, мулових відкладень, двокомпонентної композиції на основі мулу і торфу, тирси, трьохкомпонентної композиції на основі торфу, мулових відкладень та тирси зображені на рис. 6 і 7 .

Двокомпонентна композиція на основі мулу i торфу займає положення поміж ізотермами торфу та мулових відкладень (рис. 6). При $\varphi=0,4$ рівноважна вологість всіх зразків різна, що свідчить про неоднорідний склад матеріалу. Для торфу - $11 \%$, для мулових відкладень близько 2 \%, а для композиції $5 \%$ і є подібною до мулових відкладень.

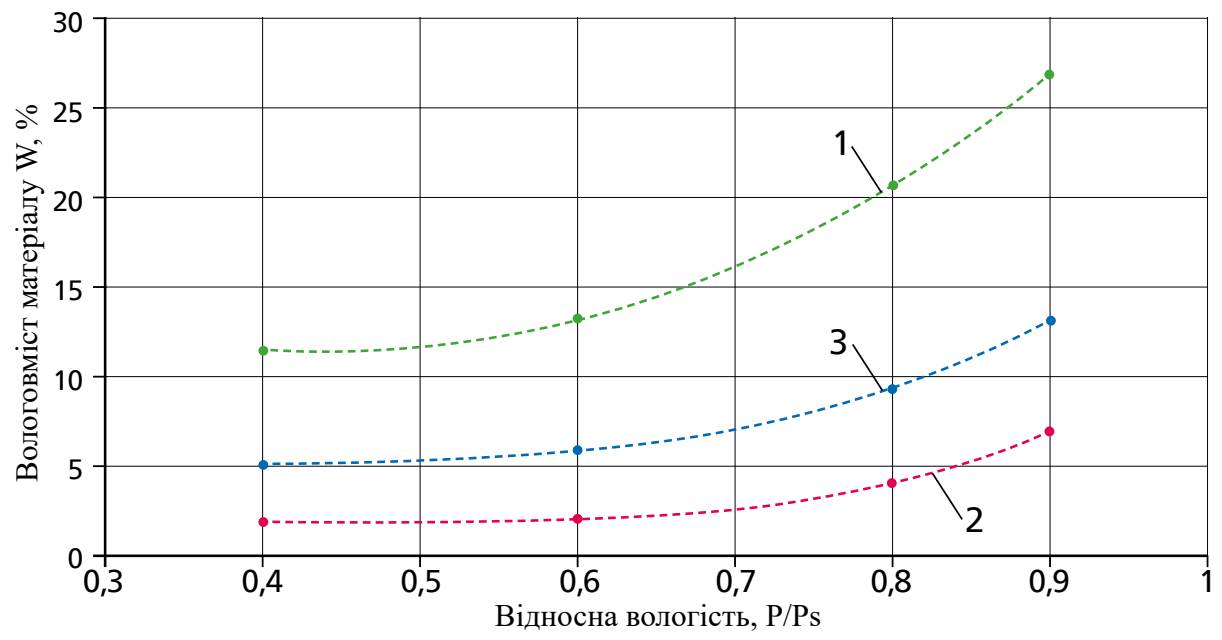

Рис. 6. Ізотерми адсорбції водяної пари

1 - торф; 2 - мулові відкладення; 3 - двокомпонентна композиція на основі мулу і торфу

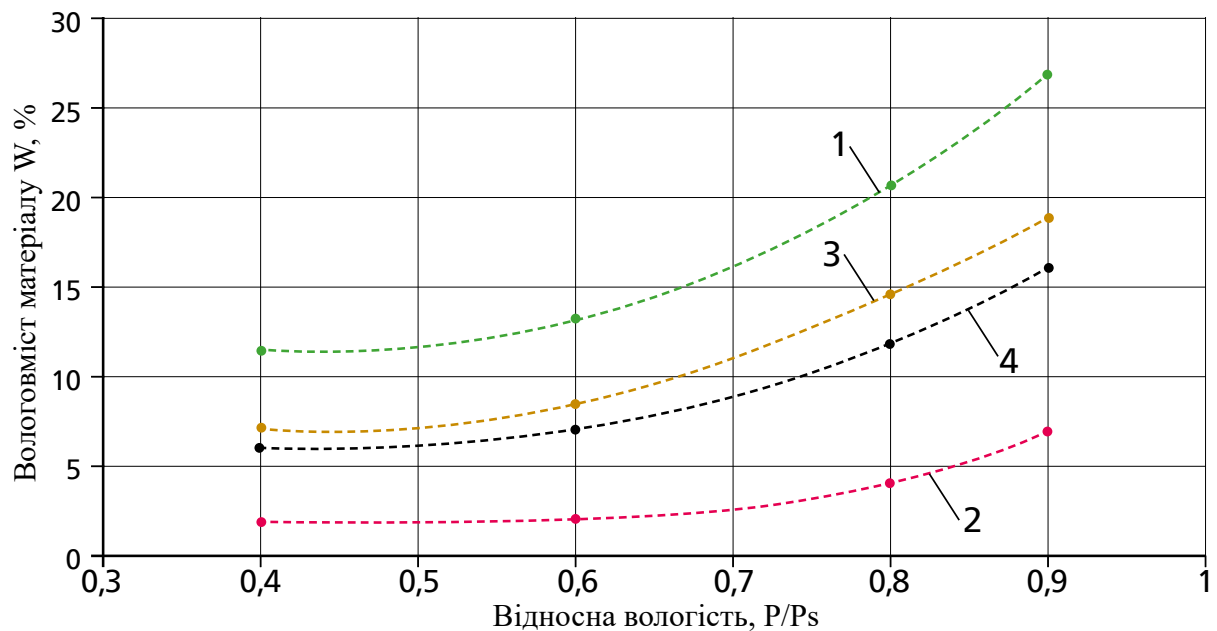

Рис. 7. Ізотерми адсорбції водяної пари

1 - торф; 2 - мулові відкладення; 3 - тирса;

4 - трьохкомпонентна композиція на основі торфу, мулових відкладень та тирси 
Як видно з рис. 7, криві для трьохкомпонентної композиції на основі торфу, мулових відкладень та тирси, а також тирси, розміщені поміж кривих для торфу та мулових відкладень. Для трьохкомпонентної композиції при $\varphi=0,4$ ізотерми мають рівноважну вологість, що складає $11 \%$, для мулових відкладень їі значення близько $2 \%$, тирси $-7 \%$, а для композиції - 6 \% та подібна до кривої тирси.

У таблиці 1 наведені рівняння експериментальних ізотерм та лінеарізованих ізотерм адсорбції для торфу, мулових відкладень, тирси та композицій на ïх основі.

\section{Висновки}

Вперше були проведені дослідження адсорбційних властивостей дво- та трьохкопонентних композицій. Під час зберігання композиційних гранул $з$ метою запобігання втрати їх технологічних властивостей рекомендується підтримувати вологість повітря на рівні 60 - 70 \%. Отримана рівноважна вологість композицій не перевищує стандартну вологість для паливних гранул (складає 20 \%) та становить 6 - 7 \%. Тому вони можуть бути використані для спалювання в котлах на біомасі.
Отриману золу можна застосовувати для виробництва цегли, цементу та інших будівельних матеріалів, як наповнювача в технології виготовлення керамічних виробів.

\section{References}

1. Снєжкін, Ю.Ф., Петрова, Ж.О., Пазюк, В.М., Новікова, Ю.П. Стан технологій очищення стічних вод в Україні та світі. Теплофізика та теплоенергетика. - 2021. - 43 (1). - С. 5 - 12.

2. Петрова, Ж.О., Новікова, Ю.П. Підготовка сировини, створення композицій та гранулоутворення 3 застарілих мулових відкладень, торфу та біомаси. Кераміка наука і життя. - 2021. - 1(50). - С. 14 - 18. https://doi.org/10.26909/csl.1.2021.2.

3. Петрова, Ж.О., Снєжкін, Ю.Ф. Енергоефективні теплотехнології переробки функціональної сировини. - Київ: Наукова думка. - 2018. - 187 с.

4. Грег, С., Синг, К. Адсорбция, удельная поверхность, пористость. - М.: Мир. - 1984. - 310 с.

5. Снежкин, Ю.Ф., Боряк, Л.А., Хавин, А.А. Энергосберегающие теплотехнологии производства пищевых порошков из вторичных сырьевых ресурсов. Київ: Наукова думка. - 2004. - 228 с. 